\title{
PELATIHAN PENULISAN ESAI KREATIF BAGI PENGEMBANGAN BAKAT SASTRA ANAK PANTI MUHAMMADIYAH
}

\author{
Demeiati Nur Kusumaningrum $^{1 *}$, Fauzik Lendriyono ${ }^{1}$, Dion Maulana Prasetya ${ }^{1}$ \\ Fakultas Ilmu Sosial dan Ilmu Politik, Universitas Muhammadiyah Malang, Malang, Indonesia \\ *Penulis Korespondensi : demeiati.nk@umm.ac.id
}

\begin{abstract}
Abstrak
Pelatihan penulisan esai kreatif merupakan bagian dari gerakan literasi Indonesia yang menargetkan pengembangan bakat sastra anak panti asuhan dan pembentukan bibit-bibit baru komunitas literasi. Mewujudkan insan yang berkualitas dan bermanfaat bagi sesama adalah nilai-nilai yang mendasari realisasi program pengabdian masyarakat dengan sasaran anak-anak panti asuhan Muhammadiyah di daerah Malang dan sekitarnya. Berdasarkan observasi dan wawancara dengan Majelis Pelayanan Sosial, kegiatan ini dilaksanakan dengan pertimbangan (1) anak-anak panti minim mendapatkan materi dan pendampingan tentang teknis menulis karya sastra, (2) belum banyak media untuk menampung kreatifitas menulis kreatif bagi anak-anak panti, (3) minimnya event pelatihan menulis yang menghasilkan publikasi karya sastra, dan (4) perlunya apresiasi untuk mempublikasikan karya tulis terpilih baik dalam wujud cetak maupun daring. Hasil pelatihan penulisan esai kreatif santri LKSA direncanakan untuk dipublikasikan sebagai buku kompilasi karya sastra. Sayangnya, berdasarkan hasil pelatihan, 50 persen mampu menulis puisi, 40 persen senang menulis cerpen, dan sisanya opini singkat. Namun demikian, 40 persen diantaranya perlu penyempurnaan penulisan Sehingga, perlu tindak lanjut kegiatan pelatihan untuk menyempurnakan tulisan masing-masing santri.
\end{abstract}

Kata kunci: Literasi; Malang; Muhammadiyah; Santri; Sastra.

\begin{abstract}
Creative essay writing training is part of the Indonesian literacy movement which targets the development of literary talents of orphanages and the formation of new generation of the literacy community. Realizing qualified and beneficial human beings are values that underlie the realization of community service programs targeting Muhammadiyah orphanage children in Malang and surrounding areas. Based on observations and interviews with the Social Services Assembly, this activity was carried out with the consideration that (1) the orphanage children had minimal material and assistance on technical writing of literary works, (2) there were not many media to accommodate creative writing creativity for orphans, (3) the lack of writing training events that result in the publication of literary works, and (4) the need for appreciation for publishing selected written works both in print and online. The results of LKSA santri creative essay writing training are planned to be published as a compilation book of literary works. Unfortunately, based on the results of the training, 50 percent were able to write poetry, 40 percent liked writing short stories, and the rest were short opinions. However, 40 percent of them need improvement in writing. Therefore, it is necessary to follow up on training activities to improve the writing of each student.
\end{abstract}

Keywords: Literacy; Malang; Muhammadiyah; Santri; Literature.

\section{PENDAHULUAN}

Muhammadiyah adalah organisasi yang menaruh perhatian besar pada pelayanan sosial, baik pelayanan yang sifatnya komersial maupun pelayanan yang didasarkan atas nilai kemanusiaan. Peran dan keberadaan Muhammadiyah bertujuan memberikan nilai manfaat kepada masyarakat. Di bidang pelayanan sosial, Muhammadiyah memiliki majelis khusus yang fokus melakukan praktik- praktik pelayanan sosial kepada masyarakat di mana dikenal sebagai Majelis Pelayanan Sosial (MPS). Panti asuhan atau yang dikenal dengan istilah Lembaga Kesejahteraan Sosial Anak
(LKSA) menjadi tanggungjawab MPS (Romadona, 2018).

Program pengabdian masyarakat ini berangkat dari ide tentang peningkatan pemberdayaan anggota LKSA di Malang Raya melalui gerakan literasi pelajar. Tim pengusul berupaya mensinergikan visi misi dari Kementerian Pendidikan dan Kebudayaan terkait gerakan literasi di Indonesia dengan memfasilitasi pelatihan menulis esai kreatif. Pelatihan menulis esai kreatif dipahami sebagai transfer pengetahuan dan ketrampilan yang mengikuti semangat dari program 
pengabdian masyarakat yang telah ada (Bramasta \& Nirwansyah, 2018; Kasiyan dkk, 2019; Kurnianingsih dkk, 2017; Silvana \& Darmawan, 2018). Pada berbagai program pengabdian masyarakat yang mengemuka di Indonesia, bentuk pelatihan dan pendampingan nyatanya berdampak pada peningkatan kualitas SDM dan ekonomi masyarakat (Hendarmin dkk, 2018; Puspawiningtyas dkk, 2017; Watemin dkk, 2017).

Selain itu, peningkatan minat membaca dan menulis para pelajar sangat penting. Hal ini berdasarkan hasil riset tahun 2017 bahwa masyarakat Indonesia lebih sering menonton atau mendengar dibandingkan membaca apalagi menulis. Sementara, pemahaman dari membaca yang diaktualisasikan melalui tulisan belum menjadi budaya di Indonesia. Adapun di tingkat sekolah, mading masih didominasi oleh liputan kegiatan OSIS dibandingkan sajian karya cerita pendek atau puisi dari para pelajar. Hal ini didukung oleh kondisi di mana, perpustakaan lebih menaruh perhatian pada buku-buku pelajaran dibandingkan dengan novel, biografi, ensiklopedia, dan referensi yang sifatnya pengayaan kemampuan sastra. Penguasaan dalam bidang sains masih diapresiasi lebih tinggi dibandingkan dengan kemampuan dalam bidang sastra (Alfarikh, 2017).

Berdasarkan penelitian Wahdati (2015) membaca dan menulis merupakan sebuah aktivitas dakwah. Aktivitas dakwah Islam tersebut bisa dilakukan melalui tiga hal meliputi dakwah bil Hal, dakwah billisan dan dakwah bil kitabah atau dakwah bi al-Qalam. Aktivitas menulis termasuk dalam dakwah bil kitabah, yang merupakan dakwah lewat media yang dalam hal ini difokuskan pada media tulisan. Mempertimbangkan idealisme tersebut di atas, tim pengabdian masyarakat meyakini bahwa para santri LKSA Muhammadiyah dan Aisyiyah yang ada di Malang Raya perlu pengembangan bakat sastra dan ketrampilan menulis (Wahdati, 2015).

Berdasarkan portal Muhammadiyah Jawa Timur, terdapat 5 (lima) panti asuhan di Kota Malang, 5 (lima) di Kab. Malang dan 1 (satu) di Kota Batu (PWM Jatim, tt). Dari 12 LKSA, terdapat kurang lebih 30 (tiga puluh) anak asuh yang bersekolah di SMA/SMK/MA dan kurang lebih 40 (empat puluh) anak asuh yang bersekolah di SMP/MTs. Beberapa diantara anak asuh ini pernah mengikuti program pelatihan menulis untuk konten website yang diselenggarakan tahun 2018 (Lendriyono dkk, 2019). Potensi mitra lainnya adalah persamaan ideologi organisasi, yakni berada di bawah persyarikatan Muhammadiyah yang mendukung citacita nasional - "mencerdaskan kehidupan bangsa" Indonesia.
Bagan 1. Masalah dan Solusi Mitra.

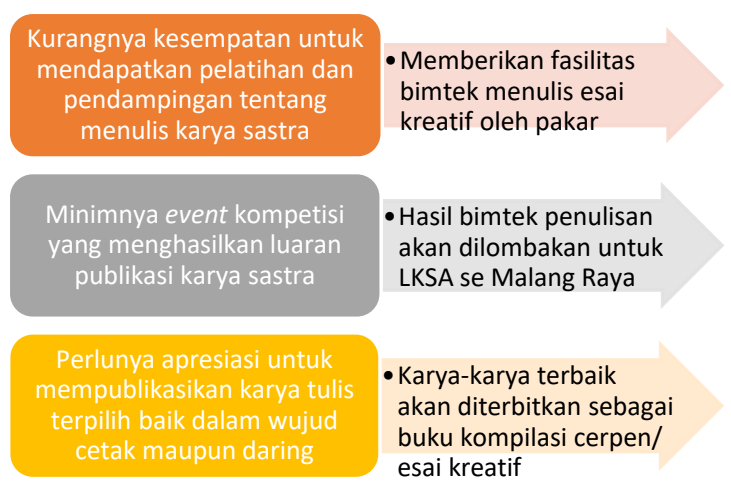

Program Pengabdian Masyarakat ini bertujuan untuk meningkatan potensi dan kreatifitas anak asuh sebagai bagian dari upaya pemberdayaan masyarakat dan dukungan bagi gerakan literasi Indonesia. Dengan bentuk kegiatan pelatihan dan kompetisi menulis esai kreatif bagi anak asuh LKSA Muhammadiyah dan Aisyiyah se Malang Raya, ditargetkan anak-anak asuh memiliki kemampuan menulis untuk mengembangkan gagasan/ ide, wawasan, dan kepercayaan diri. Selain itu, melalui kompetensi penulisan, diharapkan anak-anak LKSA mempunyai kebanggaan atas hasil karya mereka dan menjadi tahapan berkelanjutan untuk meningkatkan kompetensi menulis yang sudah ada.

\section{BAHAN DAN METODE}

Secara umum, program kegiatan ini dibagi menjadi 3 (tiga) tahap: (1) Pelatihan anak asuh LKSA Muhammadiyah dan Aisyiah se- Malang Raya dalam format workshop. (2) Pendampingan dan monitoring kemajuan pelatihan yang akan disempurnakan menjadi karya cerpen/ esai kreatif. (3) Hasil seleksi kompetisi menulis cerpen terbaik dipublikasikan dalam bentuk buku kompilasi

Adapaun target luaran dari program pengabdian masyarakat ini adalah (1) adanya peningkatan kemampuan menulis kreatif/sastra (cerpen) sebagai bagian dari dukungan gerakan literasi di Indonesia. (2) Terbangunnya kepercayaan diri anak asuh LKSA untuk menghasilkan karya sastra yang berkesan positif bagi diri sendiri maupun khalayak umum pembacanya. (3) Sebagai rekomendasi bagi event tahunan pengurus MPS Muhammadiyah dan Aisyiyah se Malang Raya sekaligus ajang silaturahmi di tingkat regional Jawa Timur.

\section{HASIL DAN PEMBAHASAN}

Program pengabdian masyarakat berbentuk kegiatan pelatihan penulisan esai kreatif dilaksanakan pada Jumat 19 April 2019 bertempat di Lab. Kesejahteraan Sosial - FISIP, Masjid AR. Fachrudiin lt. 1 Universitas Muhammadiyah Malang (gambar 1). Pakar nasional yang dipilih adalah seorang penulis opini dan mantan ka. Prodi Ilmu Komunikasi UMM, lulusan Curtin University Australia - Sugeng Winarno, M.A. 


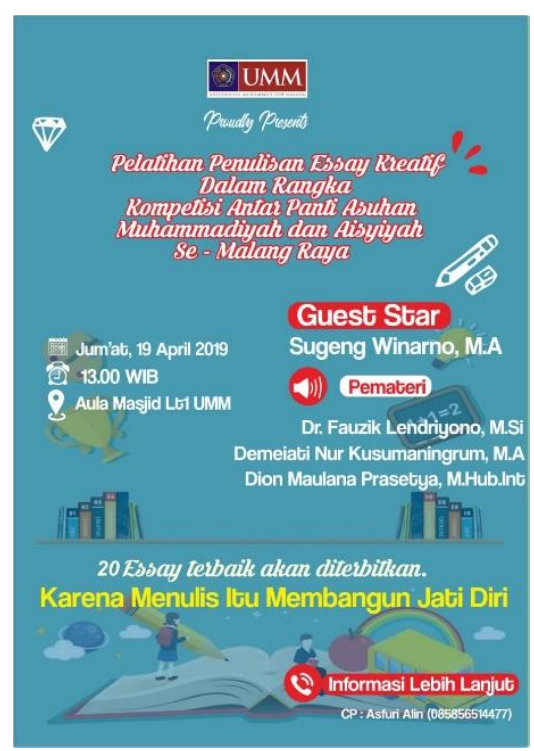

Gambar 1. Poster

Tim pengabdian dibantu oleh asisten dan laboran Kesos berjumlah 3 (orang) yaitu Effy Kusnaningtyas, Asfuri Alin, dan Yuni Permataningtyas sebagai pendukung logistik dan jaringan komunikasi teknis lapangan (gambar 2). Adapun untuk mengkomunikasikan kegiatan dan mempermudah teknis pelaksanaan, tim pengabdian membentuk grup komunikasi melalui whatsapp (wa group).

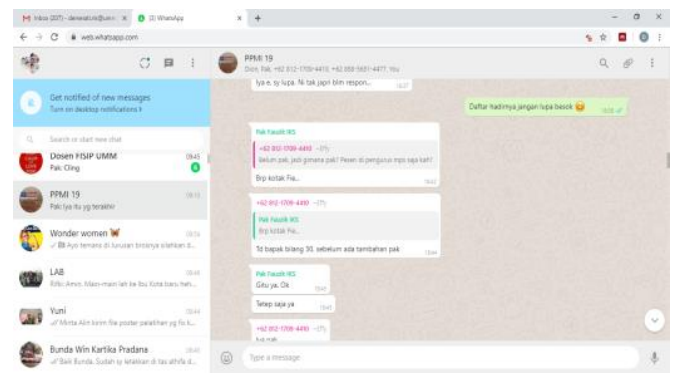

Gambar 2. Wa Group.

Kegiatan pelatihan penulisan esai kreatif mengundang seluruh LKSA Muhammadiyah dan Aisyiyah seMalang Raya. Dari poster yang dipublikasikan, pada awal pendaftaran data yang masuk berasal dari 5 (lima) panti asuhan, yaitu Ulil Absor - DAU, Riverside DAU, Al Falah - Lawang, Al Amin - Kepanjen, dan Darul Arqam - Pakisaji sejumlah 15 (limabelas) perwakilan siswa (tabel 2.). Terdapat satu tambahan siswa yang menyusul ketika pelaksanaan pelatihan. Sayangnya, dari pendaftaran awal delegasi LKSA, terdapat (5) lima orang perwakilan berhalangan hadir ketika hari pelaksanaan (tabel 3).

Sesuai dengan target luaran program pengabdian masyarakat ini yaitu peningkatan kemampuan menulis kreatif/sastra (cerpen) sebagai bagian dari dukungan gerakan literasi di Indonesia, dan; terbangunnya kepercayaan diri anak asuh LKSA untuk menghasilkan karya sastra yang berkesan positif bagi diri sendiri maupun khalayak umum pembacanya, penting bagi tim pelaksana untuk memberikan materi dan pendampingan tentang menulis esai kreatif.
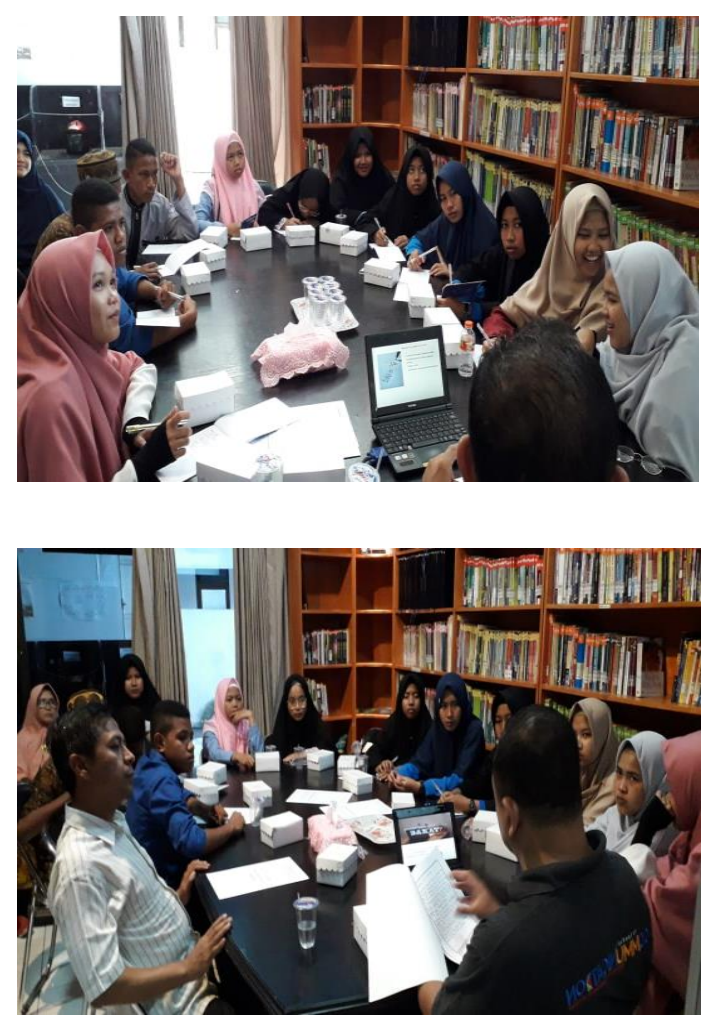

Gambar 3. Peserta Pelatihan.

Tabel 2. Daftar Peserta Awal Pendaftaran

\begin{tabular}{|l|l|c|}
\hline No. & \multicolumn{1}{|c|}{ Nama } & \multicolumn{1}{c|}{ LKSA } \\
\hline 1. & $\begin{array}{l}\text { 1. Muhammad Isa } \\
\text { Anshori } \\
\text { 2. Fakhri Ramadhan } \\
\text { 3. Sukasman Kamil }\end{array}$ & \\
\hline 2. & $\begin{array}{l}\text { 1. Winda Setyawati } \\
\text { 2. Anggun Ria } \\
\text { maghfiroh } \\
\text { 3. Siti Roviqoh }\end{array}$ & Al Amin Kepanjen \\
\hline 3. & $\begin{array}{l}\text { 1. Khorik } \\
\text { 2. Lala } \\
\text { 3. Indah }\end{array}$ & Riverside DAU \\
\hline 4. & $\begin{array}{l}\text { 1. Masduki } \\
\text { 2. Roby Firmansyah } \\
\text { 3. Fatkur Roji }\end{array}$ & Darul Arqom \\
\hline 5. & $\begin{array}{l}\text { 1. Nur Afifah } \\
\text { 2. Dinda Fitri Arya Sari } \\
\text { 3. Jihan Nuzuli } \\
\text { Ashariyah }\end{array}$ & Al Falah Lawang \\
\hline
\end{tabular}

Tabel 3. Daftar Peserta Pelatihan 19 April 2019.

\begin{tabular}{|l|l|c|c|}
\hline No. & \multicolumn{1}{|c|}{ Nama } & LKSA & Kehadiran \\
\hline 1. & 1. Muhammad & Ulil & Hadir \\
& Isa Anshori & Absor & Hadir \\
& 2. Fakhri & DAU & Hadir \\
& Ramadhan & & \\
& 3. Sukasman & & \\
& Kamil & & \\
\hline 2. & 1. Winda & Al Amin & Hadir \\
& Setyawati & Kepanjen & Hadir \\
\hline
\end{tabular}




\begin{tabular}{|l|l|c|c|}
\hline & $\begin{array}{l}\text { 2. Anggun Ria } \\
\text { maghfiroh } \\
\text { 3. Siti Roviqoh }\end{array}$ & & Hadir \\
\hline 3. & 1. Khorik & Riverside & Absen \\
& 2. Lala & DAU & Absen \\
& 3. Indah & & Hadir \\
& Permata Rizky & & Hadir \\
& 4. Sari & & \\
& Tasbillah & & \\
\hline 4. & 1. Masduki & Darul & Absen \\
& 2. Roby & Arqom & Absen \\
& Firmansyah & Pakisaji & Absen \\
& 3. Fatkur Roji & & \\
\hline 5. & 1. Nur Afifah & Al Falah & Hadir \\
& 2. Dinda Fitri & Lawang & Hadir \\
& Arya Sari & & Hadir \\
& 3. Jihan Nuzuli & & \\
& Ashariyah & & \\
\hline
\end{tabular}

Pada saat pelatihan tanggal 19 April 2019, tim pelaksana menyampaikan tentang apa makna kemampuan menulis bagi gerakan literasi Indonesia, apa saja wujud tulisan kreatif, bagaimana perkembangan dunia menulis dan ragam prestasi anak bangsa, serta tips menulis bagi pemula. Sementara, pakar komunikasi dan kolumnis nasional - Sugeng Winarno menekankan tentang apa itu esai kreatif, pentingnya menulis esai, tahapan menulis esai kreatif, dan teknis membangun gagasan serta motivasi yang mampu menyemangati para peserta (gambar 4).

Pada sesi pelatihan, peserta mempraktikkan tahapantahapan membuat sebuah esai kreatif. Untuk mempermudah para peserta memulai membuat karya, maka dibuat kelompok. Pada saat pelatihan, terdapat 4 kelompok yang mewakili masing-masing LKSA. Masing-masing kelompok mencoba menyusun ide dan gagasannya sesuai dengan arahan pemateri.

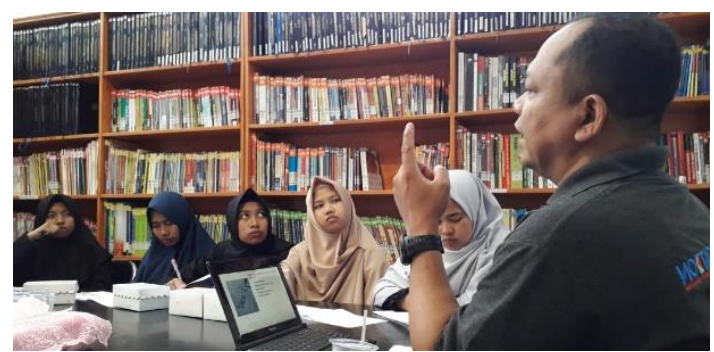

Gambar 4. Pemateri Kolumnis Nasional.

Dari hasil praktik penulisan, keempat kelompok memilih menulis esai. Tiga kelompok yang berasal dari LKSA Al Amin, Riverside, dan Al Falah sudah mampu mengembangkan kerangka karangan menjadi bentuk artikel opini sederhana. Sedangkan tim yang berasal dari LKSA Ulil Absor, masih berproses sampai membuat kerangka karangan.

Sebagai contoh proses pelatihan, naskah milik Siti Rofiqoh dari PPAM Al-Amin ketika pelatihan tertarik menulis tentang esai "Tangan Kiri itu Juga Baik". Naskah terdiri dari 5 (lima) paragraf. Siti masih belum mampu merangkai sebuah paragraf yang utuh. Sebuah paragraf setidaknya terdapat gagasan utama dan beberapa kalimat pendukung, namun pada naskah Siti paragraf kedua hanya terdiri dari satu kalimat. Paragraf ketiga pun terdiri dari poin-poin yang belum menunjukkan gagasan yang utuh, sebagai berikut

"Keadaan fisik yang diberikan Allah kepada manusia haruslah di terima dengan ikhlas tak perlu kita mencela meskipun keadaannya cacat, sesungguhnya takdir Allah sesuai dengan kebutuhan hambanya.

Begitu juga tangan kiri yang dianggap oleh sebagian besar orang Indonesia "tangan jelek" padahal dampak positif dari tangan kiri banyak sekali, seperti;

- Mencuci baju

- Memasak

- Mengetik dengan metode 10 jari

- Mengancingkan baju

Bahkan ada yang menulis dengan tangan kiri. Bayangkan saja kegiatan diatas tanpa kanan kiri apa jadinya?"

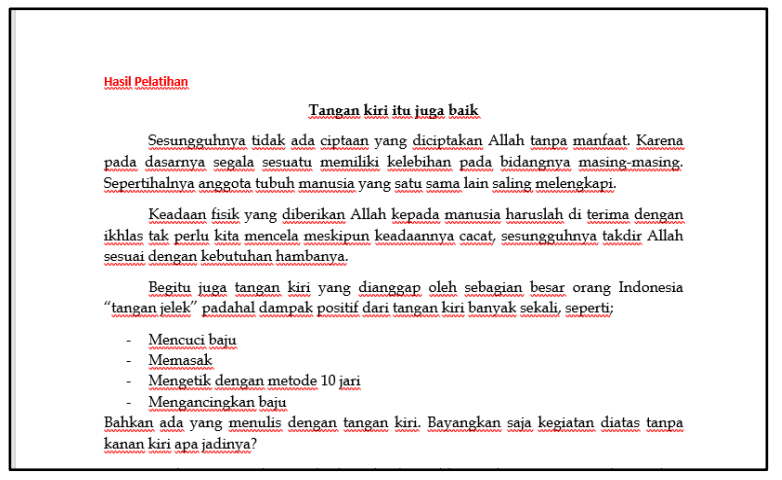

Pasca pelatihan dan pendampingan, Siti Rofikoh beralih untuk membuat judul baru yaitu "Stop Kekerasan Anak Dalam Bingkai Islami”. Dalam naskah yang baru, tampak bahwa Siti mampu menyusun paragraf yang baik dan mengandung makna yang menggambarkan gagasan utama dan gagasan pendukungnya. Hal ini dapat dipahami dari paragraf pertama,

"Seorang anak merupakan berkah karunia rahmat dari Allah SWT dan dipercaya akan membawa rezeki kepada orang tuanya. Namun, di era zaman milenial ini, kekerasan pada anak kian meledak di seluruh dunia. Kekerasan secara (fisik maupun psikis), pelecehan dan kejahatan sosial kini kian memprihatinkan. Khususnya di Indonesia yang merupakan negara berkembang dengan penduduknya mayoritas islam terbesar nomor dua di dunia setelah Arab."

Dalam rangka mencapai target luaran membentuk komunitas penulis yang berasal dari masing-masing LKSA, tim pengabdian masyarakat pasca pelatihan telah membina beberapa pendamping LKSA untuk menjadi ujung tombak atau motivator anggotaanggotanya. Sehingga, pada saat pelatihan, tim turut mengundang para pendamping teknis untuk bersamasama mensinergikan visi misi program yaitu mengembangkan kreatifitas anak-anak panti dalam bidang menulis karya sastra. 
Dalam proses pendampingan penulisan, tim juga menghadapi beberapa kendala antara lain; 1) Sulitnya komunikasi efektif antara tim dengan pendamping lapangan dan para peserta. Untuk mengembangkan naskah, para peserta tidak memiliki infrastruktur seperti jaringan internet dan smartphone sehingga kurang termotivasi. 2) Peserta belum fokus menulis karena harus membagi waktu dengan kegiatan yang lain. Hampir semuanya sibuk mengerjakan tugas-tugas sekolah.

Berdasarkan penilaian terhadap kompetensi menulis esai kreatif, tim pelaksana menetapkan "Indikator Capaian Target Kompetensi Penulisan Karya Sastra" dengan 3 (tiga) tingkatan sebagai berikut;

a) Tingkat 1: Penulis mampu menyampaikan gagasannya berupa tulisan/ outline sehingga perlu pendampingan lebih lanjut

b) Tingkat 2: Penulis mampu menyampaikan gagasannya dalam wujud karya esai, opini, atau cerpen namun perlu perbaikan sistematika penulisan, substansi logika berpikir, dan gaya penyampaian (bahasa).

c) Tingkat 3: Penulis mampu menyampaikan gagasannya dalam wujud karya esai, opini atau cerpen. Memiliki sistematika penulisan yang runtut, logika berpikir yang logis, gaya bahasa yang sesuai namun perlu penyempurnaan hingga layak diterbitkan.

Berdasarkan hasil pelatihan dan pendampingan, tim mengevaluasi perkembangan kemampuan menulis para peserta. Sejumlah (10) sepuluh peserta menuliskan judul baru untuk karangannya. Topik esai pada saat pelatihan cenderung ditinggalkan. Sebanyak 50\% peserta lebih memilih untuk menyusun format baru berbentuk puisi, $40 \%$ berbentuk cerpen, dan $10 \%$ esai/ artikel opini.

Berdasarkan analisis konten karya, sebesar 50\% mampu menyelesaikan tulisannya dan $50 \%$ sisanya masih perlu perbaikan dan penyempurnaan. Sayangnya, dari kesepuluh peserta yang mengumpulkan perkembangan penulisannya, 3 orang yang bertahan dari awal pelatihan. Sementara 7 orang sisanya aktif sebagai peserta pendampingan.

\section{KESIMPULAN}

Pembangunan manusia dan daya saing bangsa merupakan variabel determinan yang menguatkan posisi bangsa di era global. Kapasitas pemberdayaan masyarakat menjadi kekuatan lembaga perguruan tinggi dan pendidikan di seluruh Indonesia. Sebagaimana nilai-nilai kemanfaatan yang menjadi basis amal usaha Muhammadiyah, program pengabdian masyarakat ini menaruh perhatian pada pengembangan bakat sastra anak-anak panti asuhan binaan Muhammadiyah di Malang dan sekitarnya.

Pelatihan penulisan esai kreatif ini cukup diminati oleh anak-anak panti. Terdapat 7 panti yang terlibat dalam kegiatan ini dan telah mengirimkan delegasinya yang terbaik. Adapun $90 \%$ peserta mampu mengekspresikan gagasannya melalui tulisan, walaupun $40 \%$ masih membutuhkan penyempurnaan. Sebagian besar anakanak panti senang menulis puisi. Sisanya lebih menyukai cerpen dan opini singkat. Topik yang diangkat lebih merujuk pada masalah sosial yang relatif sering dijumpai, perasaan sebagai anggota keluarga panti, dan judul imajinatif lainnya. Namun program ini belum mampu mencapai target luaran terakhir berupa naskah siap terbit mengingat kemampuan anak-anak LKSA masih belum memadai dan membutuhkan pembinaan lebih intensif. Bagaimana pun minat mereka terhadap sastra dan semangat untuk berproses dalam penulisan esai kreatif patut diapresiasi.

\section{UCAPAN TERIMA KASIH}

Ucapan terima kasih kami sampaikan kepada Universitas Muhammadiyah Malang melalui DPPM yang telah memberikan dukungan dana dan akademik untuk menyelesaikan program pengabdian ini. Kami sampaikan terima kasih dan apresiasi kepada temanteman LKSA se Malang Raya yang telah berpartisipasi dalam kegiatan penulisan ini.

\section{DAFTAR PUSTAKA}

Alfarikh, A. (2017). Menumbuhkan budaya literasi di kalangan pelajar. In The 1st International Conference on Language, Literature and Teaching (pp. 959-967). UMS. Retrieved from https://publikasiilmiah.ums.ac.id/xmlui/bitstrea $\mathrm{m} /$ handle/11617/8951/i53.pdf?sequence $=1$

Bramasta, D., \& Nirwansyah, A. W. (2018). Membangun Kemampuan Spasial Lewat Pelatihan Pemetaan Digital Berbasis Sistem Informasi Geografis Untuk Aparatur Negara. JPPM (Jurnal Pengabdian Dan Pemberdayaan Masyarakat), 2(1), 73-78. Retrieved from http://jurnalnasional.ump.ac.id/index.php/JPPM /article/view/2163/1871

Hendarmin, H., Kartika, M., \& Pebrianti, W. (2018). Pelatihan dan Pendampingan Pengolahan Komoditi Kelapa. JPPM (Jurnal Pengabdian Dan Pemberdayaan Masyarakat), 2(1), 1-6. Retrieved from http://jurnalnasional.ump.ac.id/index.php/JPPM /article/view/1706/1860

Kasiyan, K., Zuhdi, B. M., Hendri, Z., Handoko, A., \& Sitompul, M. (2019). Pelatihan Penulisan Karya Ilmiah Untuk Peningkatan Profesionalisme Guru. JPPM (Jurnal Pengabdian Dan Pemberdayaan Masyarakat), 3(1), 47-53. Retrieved from http://jurnalnasional.ump.ac.id/index.php/JPPM /article/view/3128/2435

Kurnianingsih, I., Rosini, R., \& Ismayati, N. (2017). Upaya Peningkatan Kemampuan Literasi Digital bagi Tenaga Perpustakaan Sekolah dan Guru di Wilayah Jakarta Pusat Melalui Pelatihan Literasi Informasi. Jurnal Pengabdian Kepada Masyarakat (JPKM), 3(1). Retrieved from https://journal.ugm.ac.id/jpkm/article/viewFile/ 25370/18954 
Lendriyono, F., Kusumaningrum, D. N., \& Hardyanti, W. (2019). Penguatan "Institutional Branding" Muhammadiyah Kabupaten Malang Melalui Pengelolaan Website Majelis Pelayanan Sosial. ADIMAS, 3(1), 16-23. Retrieved from http://journal.umpo.ac.id/index.php/adimas/artic le/view/1439/1015

Puspawiningtyas, E., Pamungkas, R. B., \& Hamad, A. (2017). Upaya Meningkatkan Pengetahuan Bahan Tambahan Pangan Melalui Pelatihan Deteksi Kandungan Formalin dan Boraks. JPPM (Jurnal Pengabdian Dan Pemberdayaan Masyarakat), 1(1). Retrieved from http://jurnalnasional.ump.ac.id/index.php/JPPM /article/view/1220/1236

Romadona, D. (2018). MPS Ajak Santri LKSA Sebagai Penggerak Literasi. Retrieved September 13, 2019, from http://malang.muhammadiyah.or.id/berita14571-detail-mps-ajak-santri-lksa-sebagaipenggerak-literasi.html

Silvana, H., \& Darmawan, C. (2018). Pendidikan Literasi Digital di Kalangan Usia Muda di Kota Bandung. PEDAGOGIA, 16(2), 146. https://doi.org/10.17509/pdgia.v16i2.11327

Wahdati, A. K. (2015). Pengaruh Minat Membaca Terhadap Terhadap Kemampuan Menulis Cerpen Islami Pada Forum Lingkar Pena (FLP) Cabang Semarang. Universitas Islam Negeri Walisongo Semarang.

Watemin, Purnawanto, A. M., \& Ma'ruf, A. (2017). Pelatihan GMP dan HACCP Bagi Pengrajin Gula Kelapa Kristal. JPPM (Jurnal Pengabdian Dan Pemberdayaan Masyarakat), I(1). Retrieved from http://jurnalnasional.ump.ac.id/index.php/JPPM /article/view/1139/1230 